\title{
Factors That Affect Canadian Propensity to Direct Investment Abroad: Evidence from the Indian Real Estate Market
}

\author{
Amarjit Gill ${ }^{*}$ and Nahum Biger \\ College of Business Administration, TUI University, CA, 90630, USA
}

\begin{abstract}
This study examines the affects of Canadian investors' direct investment expertise and perception on capital losses on their propensity to directly invest in the Indian real estate market. Canadian investors were surveyed to find out the degree to which investors' direct investment expertise and perception on capital losses impact on investors' propensity to direct investment. To test the effects of the above variables, Canadian were asked about their beliefs and feelings regarding their propensity to directly invest in the Indian real estate market. They were also asked about perceptions on capital losses. We found that the degree of Canadian investors' propensity to direct investment is related to the degree of investors' investment expertise and their perception on capital losses; but the extent of these factors differ based on age and level of education of Canadian investors. The findings may be useful for investment managers.
\end{abstract}

\section{INTRODUCTION}

Foreign direct investment (FDI) in India has long been recognized to be instrumental in the economic development of the country. FDI, in the context of this study, is described as an investment in real assets (land and buildings) in foreign countries. Indian market is one of the emerging markets in the less developed economics of countries [1]. India's economic growth has been at an average of $8.6 \%$ in the last four years [2]. Overall, India has experienced considerable economic growth, with projections seeing the Indian economy nearly tripling by 2020 . India is now seen as the world's third most attractive FDI location [3]. With an estimated \$79 billion investment-grade real estate, India accounts for $0.5 \%$ of the world's investable real estate [3]. Thus, India provides a major opportunity for international real estate investors. In addition, Indian minister of commerce indicated that the FDI is safe in India [4].

Rate of return on FDI in India has been acknowledged to be among the highest in the world and much higher than in other Asian markets [4]. "Chief Economist of Export Development Canada" also argued that the exporters must first invest in the Indian market [5]. With increasing globalization of investments in recent years and economic growth in India, Canadian investors have started considering direct investment in the Indian real estate market.

Although, India provides a major opportunity for international real estate investors, foreign investors may have real or perceived concerns regarding the risk of undertaking such investments. Such concerns hinder FDI in the Indian real estate market. Growing importance of FDI has generated interest and research of foreign investment decisions of investors [6]. Among the main impediments to such investments, one can't ignore country risk factors such as political, legal, economic, corruption, confiscation, etc. These sources of risk, real or perceptional, might lead to foreign aversion to

*Address correspondence to this author at the College of Business Administration, TUI University, CA 90630, USA; E-mail: AGill@tuiu.edu undertake direct investments and even lead to capital losses in the Indian real estate market.

Despite the statements of the Indian minister of commerce in which it was indicated that the FDI is safe in India [4], most investors are reluctant to take risk in the Indian real estate market because of perceived capital losses. The FDI inflow from Canada to India is the lowest compare to the G8 countries (Canada, France, Germany, Italy, Japan, Russia, the United Kingdom, and the United States), being just $1.1 \%$ of the total FDI inflow [4]. While one of the reasons of low FDI inflow from Canada to India is the Canadian investors' propensity to take risk, other reason can be the Canadian investors' direct investment expertise. Risk in the context of this study is described as a state in which more than one outcome is possible; that is, Canadian investors can make profit or loose capital in the Indian real estate market.

Investors' risk perception plays an important role in evaluating competing investment products. In complex decision making such as real estate investment decision, investors must use heuristics and biases overconfidence, loss aversion, confirmation bias, etc. [7]. Risk judgments tend to be derived from past performance as proxies for current risk perceptions [7], which in turn, impact on investors' direct investment behavior and create reluctance to invest capital in the real estate market.

\section{IMPORTANCE OF FOREIGN DIRECT INVEST- MENT-RISK}

All business transactions involve some degree of risk. When business transactions occur across international borders, they carry additional risks not present in domestic transactions [8]. These additional risks are called country risk and include risks arising from differences in the foreign country economic structures, policies, political and legal system, unexpected changes in the exchange rate, changes in tax policies and codes, and other factors. These risk factors have negative as well as positive impact on direct investment propensity of investors to invest capital. Therefore, it is im- 
portant to understand the adverse risk factors that have negative impact on the behavior of foreign investors.

Since the Indian market is one of the emerging markets and real estate investors play an important role in the development of the global economy, it is important to understand their propensity to invest capital in this market. The purpose of this study was to explore the relationship between investors' expertise and perceptions on capital losses and their propensity to directly invest in the Indian real estate market. In addition, this study seeks to extend and update previous studies conducted by [9] that dealt with investment attitudes and portfolio decisions of individual investors, Masters' [10] study related to investors' risk-taking propensities, Hamid's [11] study related to a comprehensive Palestinian housing policy, and Shooley and Worden's [12] research related to understanding risk tolerance and investment behavior of generation $\mathrm{X}$.

\section{RELATIONSHIP BETWEEN INVESTMENT EXPER- TISE AND INVESTMENT PROPENSITY OF INVES- TORS}

Investment expertise, in the context of this study, is defined as investors' knowledge and experience in the real estate investment. Global investors are faced with many challenges when they look towards the emerging markets [13]. Emerging markets for investment feature slightly higher risk levels than the developed nations of the world [1]. Investment risk is a multidimensional construct with four principal attributes: i) the possibility of a very large loss, ii) the possibility of a below target return, iii) the ability to control loss, and iv) the investor's level of knowledge [14].

The investor's level of expertise is one of the principal attributes that impact on propensity to direct investment. The relative importance of the investor's level of expertise is a function of idiosyncratic investor and asset characteristics. Improved investment expertise enables investors to make better investment decisions [7]. That is, the more accurately investors perceive direct investment risk, the better they understand the link between risk and return; and the better the understanding of the link between risk and return, the higher investors' propensity to direct investment.

Risk-averse investors continue to be attracted by relative stability of residential properties and buildings [11]. Investors' investment expertise has positive and negative impacts on their propensity to invest capital. That is, if Canadian investors perceive higher direct investment risk, they are reluctant to invest capital in the Indian real estate market and vice versa.

Older investors are reluctant to take higher level of risk [15]. Markese and Perritt [9] found investor attitudes were influenced by investor characteristics such as age, education, amount of total assets, and level of income. Masters [10] found that education level is not always a factor influencing investment decisions. Regardless of education level, knowledge of investments is a significant factor in an individual's willingness to take investment risks [10]. Weiss [16] indicates that taking risk means different thing to different people. What one person sees as a threat because he thinks he will fail, another person sees as a challenge because she thinks she will succeed. Therefore, there is a difference in investors' attitudes based on their age and education.
Investors, in general, and Canadian investors in particular exhibit different direct investment behaviors based on their age and the level of education. Therefore, we postulate that: i) Canadian investors who are more expert in the Indian real estate market, feel more inclined to invest capital than those who are less expert, and ii) there is difference in risk-taking propensity toward real estate investment in India by age and education.

Accordingly, the following hypothesis was formulated:

H1: The higher the level of Canadian investors' direct investment expertise in the Indian real estate market, the higher the level of propensity to invest capital.

\section{THE IMPACT OF INVESTORS' PERCEPTION OF CAPITAL LOSSES ON INVESTMENT PROPENSITY}

Capital loss is created when investors sell a capital property (e.g., land and building) for less than its adjusted cost base plus the outlays and expenses involved in selling the property. The business risk and economic uncertainty are actual sources of risk [14] that cause capital losses. Investors' perception on capital losses has negative impact on propensity to direct investment.

Different factors such as political, economic, social, legal, etc., may lead to capital losses in the global market. Researchers stated that the major risk for foreign investors in India is the bureaucracy, political interferences, high cost of capital, and a poor infrastructure [3, 17]. Other impediments are corruption and poor legal system related to protection of property rights [18], which in turn, lead to confiscation and liquidity (the ability of an investor to property on short notice without appreciable loss) threats for real estate investors. Cuervo-Cazurra [19] indicates that corruption has a negative impact on investors' direct investment behavior. Thus, corruption reduces foreign direct investment in the real estate market.

Bureaucracy risk comes in the form of red tape issues in India. Red tape issues are a fact of economic life in India [20]. The neutrality of bureaucracy has been tampered rather heavily since the mid-seventies by the political masters [21]. Investors (business owners) often complain, and perhaps rightly so, that they are more the victims than the perpetrators of economic crimes in a regime of government controls and bureaucratic stickiness [21]. Thus, investors perceive that bureaucracy can lead to capital losses in India and they decide not to invest in the international market.

Political risk is defined as negative perceptions emanating from internal instability, intergovernmental relationships, anticipated or unanticipated government actions, or government discontinuities all brought about by social, economic, or political imperatives that exist in a country's internal or relevant external environment [6].

Investment observers have been worried about political developments that have been taking place just as the country is trying to shake off its history of tight government control on all aspects of the economy [22]. In addition, political events do not merely have a potential to cause losses, but actually do cause losses in Asia [23]. Property investors in Asia have to contend with high political risk factors in their search for returns [24]. Typical risks for foreign investors in Asian markets relate to business interruption following po- 
litical actions [25]. Therefore, foreign investors are concerned about political risk in India before they make final decision as to invest money in the real estate market.

Corruption and poor legal system of India are additional risk factors that investors are concerned about. Since increasingly expensive elections are not state-financed, the stimulus to politics-business corruption remains strong in an otherwise remarkably resilient in Indian democratic system [21]. In addition, the labor market is restricted by a number of laws and regulations, of which the most important are those concerning the retrenchment of employees. Companies employing more than 100 workers need government's permission to lay off workers, and this permission is often withheld by corrupt government officers. Such restrictions have hindered foreign investment in India [26].

The Indian legal system is notoriously slow. The regulatory system is not immune from policy reversals due to pressure from vested interests and inter-ministry rivalries. Disputes often take decades to resolve and many foreign companies build in clauses allowing for international arbitration. Labor relations are fairly poor, but the incidence of strike action in the private sector has declined in recent years, which can lead to capital losses in India.

McClearn [18] also argues that corruption and poor legal system are serious problems in India. In its latest corruption perception index, watchdog Transparency international give India an appalling rating of 2.8 out of 10 . A score below 3 indicates "rampant corruption" [18]. These corruption and poor legal system risk factors can lead to capital losses in the Indian real estate market. Therefore, corruption and poor legal system risk factors lead to investors' capital loss perception.

Economic risk refers to a significant change in the Indian economic structure or growth rate that produces a major change in the expected return on foreign direct investment. The macroeconomic factors are significant risk factors in commercial property returns. Economic risk arises from the potential for detrimental changes in fundamental economic policy goals (fiscal, monetary, international, or wealth distribution). Thus, macroeconomic risks in India arise from three factors - inflation, interest rates, and fiscal stance of the government [5]. Economic risk often overlaps with political risk because both deals with policy of the Indian government, which in turn, leads to capital loss perceptions that has negative impact on investment decisions.

Studies have shown that risk tolerance differs across individuals with their age and education [12]. We postulate i) Canadian investors who perceive lower direct investment risk in the Indian real estate market, feel more inclined to invest capital than those who perceive higher investment risk, and ii) there is difference in investor perceptions related to capital losses and investment propensity to invest in the Indian real estate market by age and education.

Hence, the following hypothesis was formulated:

H2: The higher the level of perceived capital losses, the lower the level of Canadian Investors' propensity to direct investment in the Indian real estate market.

\section{METHOD}

\section{Measurement}

Consistent with previous research, the measures were taken from two referent studies, which in turn, are based on previous studies in behavioral finance. All measures pertaining to investors' direct investment expertise and investors' perception on capital losses were adopted from Byrne's [7] and measures pertaining to investors' propensity to direct investment were adopted from Al-Tamimi's [27]. The questionnaire was pre-tested to ensure reliability.

Age was measured by a single item which asked respondents (investors) to indicate their age group. In order to preserve respondents' privacy the categorized alternative responses were: (i) $18-29$, (ii) $30-39$, (iii) $40-49$, (iv) $50-59$, (v) 60-69, and (vi) 70 and over. The coding of this variable, age, referred to the mean age in each age category. There was only one person who indicated the age to be 70 years and over and this person's response was excluded from the sample.

Education was measured by a single item which asked respondents (investors) to indicate their level of education. Categorized alternative responses were: (i) Less Than High Scholl, (ii) High School, (iii) Some College, (iv) 4-Year College Degree (BA, BS), (v) Master's Degree, and (vi) Doctoral Degree.

\section{Investors' Investment Expertise}

Investors' direct investment expertise was operationalized as the extent to which Canadian investors are experienced and understand the Indian real estate market. Byrne [7] used the two-item tolerance-of-freedom scale, which measures the investors' knowledge and experience on investment products. These two items were selected to measure the "investors' direct investment expertise" variable. Scale items were re-worded to apply to Canadian investors in the Indian real estate market and the reliability of these reworded items was re-tested. These items are:

To what extent do you.....?

IIE1) ...understand the real estate investment risk in India?

IIE2) ...have experiences in the Indian real estate investment?

Respondents were asked to indicate their agreement with each item, using a four-point Likert scale ranging from "None" to "Extreme." Higher scores reflect higher level of investors' investment risk knowledge and experience.

Cronbach alpha was not reported by Byrne [7] for the above 2 items. We calculated a Cronbach alpha of .83 on the responses of the thirty investors who participated in the pretest of the above scale items. All two items were included in the final questionnaire.

\section{Investors' Propensity to Direct Investment}

Investors' propensity to direct investment was operationalized as the extent to which investors are inclined to invest in the Indian real estate market to: i) get rich quickly, ii) diversify risk, iii) minimize risk, and iv) earn higher rate of 
return. Byrne [7] used the eight-item tolerance-of-freedom scale, which measures the investor's propensity to invest. We selected four items to measure the "investors' propensity to direct investment" variable. Scale items were reworded to apply to the Canadian investors in the Indian real estate market and the reliability of these re-worded items was re-tested. These items are:

To what extent do you desire to invest capital in the Indian real estate market to.....?.

IIP1) ..."get rich quickly?"

IIP2) ...diversify risk?

IIP3) ...minimize risk?

IIP4) ...obtain higher rate of return?

Respondents were asked to indicate their agreement with each item, using a four-point Likert scale ranging from "None" to "Extreme." Higher scores reflect higher level of investor propensity to invest in the Indian real estate market.

Cronbach alpha was not reported by Byrne [7] for the above 4 items. We calculated a Cronbach alpha of .81 on the responses of the thirty investors who participated in the pretest of the above scale items. All four items were included in the final questionnaire.

\section{Investors' Perception on Capital Losses}

Investors' perception on capital losses was operationalized as the extent to which they perceive future capital losses in the Indian real estate market because of: i) poor political and legal system, ii) corruption, iii) the chances of confiscation, and iv) economic issues. Al-Tamimi [27] used thirty four items to measure investor behavior towards investment risk. Six items were selected to measure "investors' perception on capital losses" variable. Scale items were reworded to apply to Canadian investors in the Indian real estate market and the reliability of these re-worded items was re-tested. These items are:

To what extent do you perceive a high risk of loosing capital in the Indian real estate market because of.....?

IPCL1) ...poor political system?

IPCL2) ...poor legal system?

IPCL3) ...the chances of confiscation?

IPCL4) ...corruption?

IPCL5) ...economic issues?

IPCL6) Overall, to what extent would you be worried after you invest capital in the Indian real estate market?

Respondents were asked to indicate their agreement with each item, using a four-point Likert scale ranging from "None" to "Extreme." Higher scores reflect higher level of investors' perception on capital losses in the Indian real estate market.

Cronbach alpha was not reported by Al-Tamimi [27] for the above 6 items. We calculated a Cronbach alpha of .78 on the responses of the thirty investors who participated in the pre-test of the above scale items. All four items were included in the final questionnaire.

\section{SAMPLING FRAME, QUESTIONNAIRE DISTRIBU- TION, AND COLLECTION}

The current study consists of the population of Canadian real estate investors. Canadian real estate investors in the Lower Mainland of Canada area (North Vancouver, Vancouver, Burnaby, New Westminster, Surrey, Cloverdale, and Richmond) were chosen as a sampling frame. To solve sampling frame issues, it was ensured that subjects were selected from Canadian community only.

\section{Sampling Method, Sampling Issues, and Possible Planned Solutions}

The current study applied a convenience (non-random) sampling method to select and recruit the research participants. This method was chosen because the Canadian real estate investors are reluctant to participate in the research. Therefore, there was the possibility of sampling bias (the threat to representational ability of a sample). To avoid sampling bias, friends were educated to choose research participants who are indeed representative of the population. For example, friends were educated in order to ensure that they exclude all non-Canadian real estate investors. It was ensured that all the research participants who completed surveys were representative of the population. In addition, friends were educated to exclude all the non-Canadian real estate investors before they start collecting data.

To achieve a convenience sample, an exhaustive list of Canadian investors' names and telephone numbers in the Lower Mainland area was created to conduct telephone interviews. In addition, to set up the data gathering, a mailing list of friends' names and addresses were completed. Survey questionnaire bundles coupled with an instruction sheet were provided to participating friends for distribution.

The sample included at least 700 research participants encompassing Canadian investors. A total of 227 surveys were completed over the telephone (approximately 30\% of the surveys were completed over the telephone), through personal visits, and received by mail. One of the surveys was non-usable. This way, the response rate was $32.43 \%$. The remaining population was assumed to be similar to the selected research participants.

\section{STUDY PROCEDURES}

Canadian real estate investors in the Lower Mainland, Canada (North Vancouver, Vancouver, Burnaby, New Westminster, Surrey, Cloverdale, and Richmond) were studied.

Friends were called and visited in order to have their consent to support our research. Letters to explain the purpose of research and to ask for support were written. Once friends agreed, the questionnaire to those friends who agreed to participate in the study was delivered. Each packet contained the investor questionnaires together with one page of instructions and postage paid return envelopes.

\section{Issues Related to Confidentiality of the Research Partici- pants}

To solve confidentiality issues, all the subjects were assured that their names will not be disclosed and confidentiality will be assured. In addition, all the Canadian investors 
were requested to NOT disclose their names on the questionnaire. Since the research was based on the survey questionnaire, investors were not forced to respond to each specific question.

All the subjects were provided with stamped envelopes so that confidentiality is assured. There was no obligation for the subjects to answer my questions over the telephone and in person. To conduct telephone interview, all the subjects were asked for their permission to participate. All the subjects had right to say no over the telephone. Therefore, no one was forced to participate.

Investors' Consent Letter specifically indicated that by completing the survey, subjects have consented to participate in the study. Any information that is obtained in connection with this study and that can be identified with subjects will remain confidential and will be disclosed only with subjects' permission or as required by law.

\section{ANALYSIS AND RESULTS}

Appendix A shows statistics (mean, median, variance, standard deviation, skewness, standard error of skewness, kurtosis, and standard error of kurtosis) describing investor responses.

The investor data were treated to the same tests of skewness (a measure of the degree to which a distribution is asymmetrical) that were applied to the investor data. All the investor scales are within the range of -1 to +1 which is considered to be the range that is excellent for most research that requires using statistics appropriate to normal distributions.

We began our analysis by factor analyzing responses to the 12 items that described the respondents' feelings about their investment expertise, investment propensity, and capital losses in the Indian real estate market. The principle components analysis (a cluster analysis tool designed to capture the variance in a dataset in terms of principle components) with number of factors set to 3 and a varimax rotation explained $56.365 \%$ of the variance in the original scores. All the items loaded on the expected factors.

As can be seen in Table 1, the items loaded on the expected factors and those three factors accounted for $87.387 \%$ of the variance in the original items.

Table 1. Total Variance Explained - Rotation Sums of Square Loadings

\begin{tabular}{|c|c|c|c|}
\hline \multirow{2}{*}{ Component } & \multicolumn{3}{|c|}{ Total Variance Explained } \\
\cline { 2 - 4 } & \multicolumn{3}{|c|}{ Rotation Sums of Squared Loadings } \\
\cline { 2 - 4 } & Total & \% of Variance & Cumulative \% \\
\hline \hline 1 & 6.764 & 56.365 & 56.365 \\
\hline 2 & 3.046 & 25.385 & 81.750 \\
\hline 3 & .676 & 5.637 & 87.387 \\
\hline
\end{tabular}

We then computed Cronbach Alpha's on the above indicated clusters of items: Investors' Direct Investment Expertise 0.9168; Investors' Propensity to Direct Investment 0.9566; Investors' Perception on Capital Losses 0.9636.
We factor analyzed the question subsets so that we could calculate weighted factor scores. In terms of these weighted factor score items: two investors' direct investment expertise, four Investors' propensity to direct investment, and the six investors' perception on capital losses, loaded approximately equally.

Table 2. Rotated Component Matrix

\begin{tabular}{|c|c|c|c|}
\hline To what extent do you... & 1 & 2 & 3 \\
\hline $\begin{array}{l}\text { IIRK1) ...understand the real estate in- } \\
\text { vestment risk in India? }\end{array}$ & -.188 & .517 & .783 \\
\hline $\begin{array}{l}\text { IIRK2) ...have an experience in the Indian } \\
\text { real estate investment? }\end{array}$ & -.177 & .459 & .830 \\
\hline \multicolumn{4}{|c|}{$\begin{array}{l}\text { To what extent do you desire to invest capital in the Indian real } \\
\text { estate market to...? }\end{array}$} \\
\hline IPI1) ... "get rich quickly?" & -.182 & .887 & .266 \\
\hline IPI2) ... diversify risk? & -.161 & .902 & .188 \\
\hline IPI3) ... minimize risk? & -.147 & .901 & .236 \\
\hline IPI4) ... obtain higher rate of return? & -.165 & .901 & .218 \\
\hline \multicolumn{4}{|c|}{$\begin{array}{l}\text { To what extent do you perceive a high risk of Loosing capital in the } \\
\text { Indian real estate market because of.....? }\end{array}$} \\
\hline IPCL1) ... poor political system? & .929 & -.121 & -.073 \\
\hline IPCL2) ... poor legal system? & .926 & -.186 & -.103 \\
\hline IPCL3) ... the chances of confiscation? & .904 & -.143 & -.062 \\
\hline IPCL4) ... corruption? & .893 & -.119 & -.199 \\
\hline IPCL5) ... economic issues? & .867 & -.166 & -.127 \\
\hline $\begin{array}{l}\text { IPCL6) Overall, to what extent would you } \\
\text { be Worried after you invest capital in the } \\
\text { Indian real estate market? }\end{array}$ & .894 & -.145 & -.069 \\
\hline
\end{tabular}

Extraction Method: Principal Component Analysis. Rotation Method: Varimax with Kaiser Normalization. Rotation converged in 5 iterations.

Table 3 provides descriptive data as to describe Canadian investors' direct investment expertise, propensity to direct investment, and perception on capital losses.

\section{Testing of Hypotheses}

Data were processed with the Statistical Package for the Social Sciences (SPSS) computer program for Windows (version 11.5). We used linear regression to accept or reject our null hypotheses and used $p<.05$ as my level of significance.

\section{Relationship Between Investors' Direct Investment Ex- pertise and Investors' Propensity to Direct Investment}

It was hypothesized that the higher the level of Canadian investors' direct investment expertise in the Indian real estate market, the higher the level of propensity to invest capital.

A positive relationship between investors' direct investment expertise and investors' propensity to direct investment (see Table 4) was found; that is, the degree of investors' propensity to direct investment in the Indian real estate market is related to the degree of investors' direct investment expertise. Thus, the degree of investors' direct investment expertise improves the degree of investors' propensity to direct investment in the Indian real estate market. 
Table 3. Canadian Investors' Direct Investment Expertise, Propensity to Direct Investment, and Perception on Capital Losses ${ }^{\text {a }}$

\begin{tabular}{|c|c|c|c|c|c|}
\hline $\mathbf{Q} \#$ & Factor & None & Some & Great & Extreme \\
\hline \hline 1 & Investment Knowledge & $17.7 \%$ & $41.2 \%$ & $24.3 \%$ & $16.8 \%$ \\
\hline 2 & Investment Experience & $21.7 \%$ & $38.1 \%$ & $24.3 \%$ & $15.9 \%$ \\
\hline $\mathbf{Q} \#$ & Factor & None & Some & Great & Extreme \\
\hline \hline 1 & Propensity to Direct Investment & $23.9 \%$ & $33.2 \%$ & $27.0 \%$ & $15.9 \%$ \\
\hline 2 & Propensity to Direct Investment & $25.2 \%$ & $33.6 \%$ & $26.5 \%$ & $14.6 \%$ \\
\hline 3 & Propensity to Direct Investment & $20.8 \%$ & $39.4 \%$ & $21.2 \%$ & $18.6 \%$ \\
\hline 4 & Propensity to Direct Investment & $20.8 \%$ & $35.0 \%$ & $25.7 \%$ & $18.6 \%$ \\
\hline $\mathbf{Q} \#$ & Factor & None & Some & Great & Extreme \\
\hline \hline 1 & Capital Losses & $15.9 \%$ & $27.0 \%$ & $27.0 \%$ & $30.1 \%$ \\
\hline 2 & Capital Losses & $19.0 \%$ & $21.2 \%$ & $31.4 \%$ & $28.3 \%$ \\
\hline 3 & Capital Losses & $16.8 \%$ & $29.2 \%$ & $28.8 \%$ & $25.2 \%$ \\
\hline 4 & Capital Losses & $17.7 \%$ & $23.9 \%$ & $23.9 \%$ & $34.5 \%$ \\
\hline 5 & Capital Losses & $22.6 \%$ & $33.2 \% \mathrm{e}$ & $22.6 \%$ & $21.7 \%$ \\
\hline 6 & Capital Losses & $14.6 \%$ & $35.8 \%$ & $25.7 \%$ & $23.9 \%$ \\
\hline${ }^{2} \mathrm{~N}=226$. & & & & \\
\hline
\end{tabular}

Relationship Between Investors' Perception of Capital Losses and Investors' Propensity to Direct Investment

It was hypothesized that the higher the level of perceived capital losses, the lower the level of Canadian Investors' propensity to direct investment in the Indian real estate market.

A negative relationship between investors' perception on capital losses and investors' propensity to direct investment (see table 4) was found; that is, the higher the degree of investors' perceived capital losses, the lower the degree of investors' propensity to direct investment in the Indian real estate market. Thus, the higher the degree of investors' perceived capital losses decreases the degree of investors' propensity to direct investment in the Indian real estate market.

Note that around $53 \%\left(\mathrm{R}^{2}=0.535\right)$ of the variance in the degree of Canadian investors' perceived propensity to direct investment can be explained by the degree of perceived direct investment expertise, capital losses, and the age of in- vestors. Also note that we ran a multiple regression and a significant relationship between investors' age and propensity to direct investment was found. Conversely no significant relationship between investors' education level and investors' propensity to direct investment (see Table 4) was found. That is, investors' age negatively affects their investment propensity; the older they are, the more they are concerned about possible loss and therefore have lower propensity to undertake an investment. Interestingly the level of education does seem to have no relationship to their propensity to invest capital in the Indian real estate market. The final regression equation that was obtained was the following:

Propensity $=0.332-0.08$ Age +0.682 Expertise 0.0103 Losses

$$
\mathrm{t} \text { values }=(1.86)(13.87)(2.09)
$$

Adjusted $\mathrm{R}^{2}=0.527 ; \mathrm{F}=63.6$; Significance level $=0.000$

\section{DISCUSSION}

The main purpose of this study was to determine whether:

i) Canadian investors who are more expert (based on their age and the level of education) in the Indian real estate market, feel more inclined to invest capital than those who are less expert, and

ii) Canadian investors who perceive lower direct investment risk in the Indian real estate market feel more inclined to invest capital than those who perceive higher investment risk.

This was done by surveying a sample of Canadian investors. These investors' perceptions and judgments are the basis of our findings that: (i) Canadian investors who are more expert in the Indian real estate market, feel more inclined to invest capital than those who are less expert (see Table 4), and (ii) Canadian investors who perceive lower direct investment risk in the Indian real estate market, feel more inclined to invest capital than those who perceive higher investment risk (see Table 4). These findings lend some support to Hamid's [11] research in which he indicates that riskaverse investors continued to be attracted by relative stability of residential and buildings.

Overall, hypotheses were supported and as expected, mixed results were found based on investors' age and the level of education. The Canadian investors' education level

Table 4. Investors' Propensity to Direct Investment as Functions of Investors' Expertise and Perception on Capital Losses ${ }^{\text {a,b }}$

\begin{tabular}{|c|c|c|c|c|c|}
\hline & Un-Standardized Coefficients & Std. Error & Standardized Coefficients $^{\mathbf{c}}$ & t & Sig. \\
\hline \hline (Constant) & 0.377 & 0.196 & & 1.916 & 0.057 \\
\hline Expertise & 0.683 & 0.049 & 0.683 & 13.869 & 0.000 \\
\hline Capital Losses & -0.103 & 0.049 & -0.103 & -2.096 & 0.037 \\
\hline Age & -0.008 & 0.004 & -0.086 & -1.874 & 0.062 \\
\hline Education & -0.064 & 0.096 & -0.031 & -0.670 & 0.503 \\
\hline
\end{tabular}

${ }^{a}$ Dependent Variable: Investors' Propensity to Direct Investment

'Independent Variables: Investors' Direct Investment Expertise, Capital Losses, Age, and Education Level. Education level was dealt with as a single dummy variable with college education $v s$ not being the zero-one variable. Note that the education dummy variable is not at all significant.

${ }^{c}$ Linear Regression through the Origin. 
does not impact on their investment propensity to invest capital in the Indian real estate market. However an interesting finding of this paper is that once investors get older, their propensity to investment invest capital in the Indian real estate market goes down. These findings support Markese and Perritt's [9] and Hooker's [15] research in which they found that investor attitudes are influenced by investor characteristics such as age. In addition, our findings lend some support to Schooley and Worden's [12] research where they indicate that risk tolerance differs across individual clients (investors) based on their age.

\section{Practical Implications}

The practical implications is that if investors perceive that they have higher level of direct investment expertise, their propensity to invest capital in the Indian real estate market is perceived as higher than if it is perceived as lower; and if investors perceive that the risk of capital losses is lower, their propensity to direct investment is higher than if it is perceived higher. Results suggest that Canadian investors' direct investment behavior towards Indian real estate market is different based on their age and the level of education.

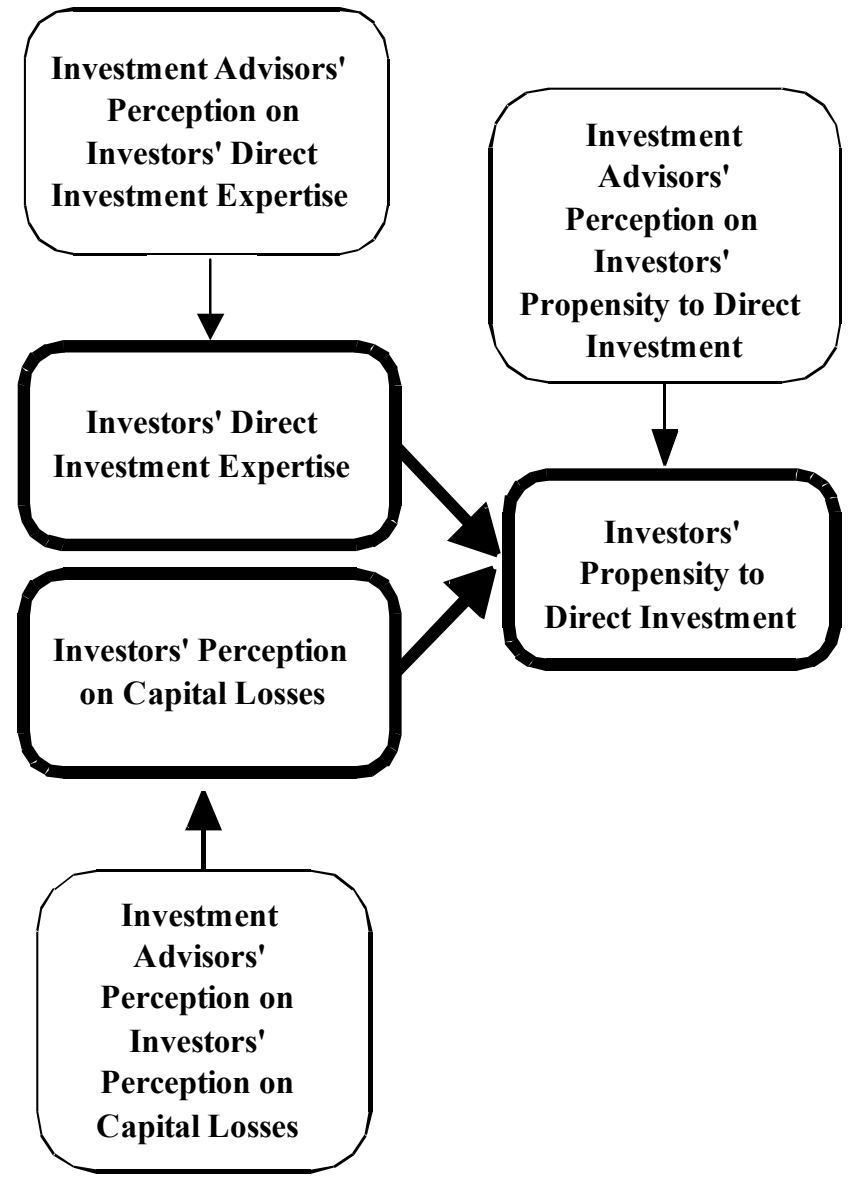

Fig. (1). Investors' Direct Investment Expertise, Perception on Capital Losses, and Propensity to Direct Investment ${ }^{\mathrm{a}, \mathrm{b}}$.

${ }^{a}$ Original Hypotheses are shown as boxes with thicker lines connected by thicker lines.

${ }^{\mathrm{b}}$ Speculations are shown as boxes with thinner lines connected by thinner lines.

\section{Future Research}

This study focused on Canadian investors, and responses were garnered regarding their direct investment expertise, perception on capital losses, and propensity to invest capital in the real estate market. While the study investigated the investor-side of this particular type of investor relationship, future research might seek to assess both investor and investment advisor perspectives to ascertain the consistency across the dyad.

The relationships and variables that we examined in this study are depicted in Fig. (1) by thick lines and arrows. Also depicted by thin lines are additional variables that should be researched. They include:

- The degree to which investment advisors perceive the relationship between investors' direct investment expertise and investors' propensity to direct investment based on age, gender, and level of education, and

- The degree to which investment advisors perceive the relationship between investors' perception on capital losses and investors' propensity to direct investment based on age, gender, and level of education.

To further enhance the generalization of the findings beyond the real estate industry, additional research in other fields is advocated, complemented by studies focusing on a longitudinal design, allowing for tracking and assessing the evolution of the determinants of investor behavior over time.

Appendix A. Canadian Investors' Data Statistics (Mean, Median, Variance, Standard Deviation, Skewness, Standard Error of Skewness, Kurtosis, and Standard Error of Kurtosis)

\begin{tabular}{|c|c|c|}
\hline $\begin{array}{l}\text { Q1) To what extent do you understand } \\
\text { the real estate investment risk in India? }\end{array}$ & Statistic & Std. Error \\
\hline Mean & 2.40 & 0.064 \\
\hline Median & 2.00 & \\
\hline Variance & 0.935 & \\
\hline Std. Deviation & 0.967 & \\
\hline Minimum & 1 & \\
\hline Maximum & 4 & \\
\hline Skewness & 0.249 & 0.162 \\
\hline Kurtosis & -0.891 & 0.322 \\
\hline $\begin{array}{l}\text { Q2) To what extent do you have } \\
\text { an experience in the Indian real estate } \\
\text { investment? }\end{array}$ & Statistic & Std. Error \\
\hline Mean & 2.35 & 0.066 \\
\hline Median & 2.00 & \\
\hline Variance & 0.983 & \\
\hline Std. Deviation & 0.991 & \\
\hline Minimum & 1 & \\
\hline Maximum & 4 & \\
\hline Skewness & 0.257 & 0.162 \\
\hline Kurtosis & -0.952 & 0.322 \\
\hline
\end{tabular}


(Appendix A) contd.....

\begin{tabular}{|c|c|c|}
\hline $\begin{array}{l}\text { Q3) To what extent do you desire to } \\
\text { invest capital in the Indian real estate } \\
\text { market to "get rich quickly?" }\end{array}$ & Statistic & Std. Error \\
\hline Mean & 2.35 & 0.067 \\
\hline Median & 2.00 & \\
\hline Variance & 1.028 & \\
\hline Std. Deviation & 1.014 & \\
\hline Minimum & 1 & \\
\hline Maximum & 4 & \\
\hline Skewness & 0.184 & 0.162 \\
\hline Kurtosis & -1.062 & 0.322 \\
\hline $\begin{array}{l}\text { Q4) To what extent do you desire to invest } \\
\text { capital in the Indian real estate market to } \\
\text { diversify risk? }\end{array}$ & Statistic & Std. Error \\
\hline Mean & 2.31 & 0.067 \\
\hline Median & 2.00 & \\
\hline Variance & 1.013 & \\
\hline Std. Deviation & 1.006 & \\
\hline Minimum & 1 & \\
\hline Maximum & 4 & \\
\hline Skewness & 0.228 & 0.162 \\
\hline Kurtosis & -1.029 & 0.322 \\
\hline $\begin{array}{l}\text { Q5) To what extent do you desire to invest } \\
\text { capital in the Indian real estate market to } \\
\text { minimize risk? }\end{array}$ & Statistic & Std. Error \\
\hline Mean & 2.38 & 0.067 \\
\hline Median & 2.00 & \\
\hline Variance & 1.027 & \\
\hline Std. Deviation & 1.013 & \\
\hline Minimum & 1 & \\
\hline Maximum & 4 & \\
\hline Skewness & 0.277 & 0.162 \\
\hline Kurtosis & -1.007 & 0.322 \\
\hline $\begin{array}{l}\text { Q6) To what extent do you desire to invest } \\
\text { capital in the Indian real estate market to } \\
\text { obtain higher rate of return? }\end{array}$ & Statistic & Std. Error \\
\hline Mean & 2.42 & 0.068 \\
\hline Median & 2.00 & \\
\hline Variance & 1.036 & \\
\hline Std. Deviation & 1.018 & \\
\hline Minimum & 1 & \\
\hline Maximum & 4 & \\
\hline Skewness & 0.154 & 0.162 \\
\hline Kurtosis & -1.076 & 0.322 \\
\hline
\end{tabular}

(Appendix A) contd.....

\begin{tabular}{|c|c|c|}
\hline $\begin{array}{l}\text { Q7) To what extent do you perceive a high } \\
\text { risk of loosing capital in the Indian real } \\
\text { estate market because of poor political sys- } \\
\text { tem? }\end{array}$ & Statistic & Std. Error \\
\hline Mean & 2.71 & 0.071 \\
\hline Median & 3.00 & \\
\hline Variance & 1.130 & \\
\hline Std. Deviation & 1.063 & \\
\hline Minimum & 1 & \\
\hline Maximum & 4 & \\
\hline Skewness & -0.210 & 0.162 \\
\hline Kurtosis & -1.209 & 0.322 \\
\hline $\begin{array}{l}\text { Q8) To what extent do you perceive a high } \\
\text { risk of loosing capital in the Indian real } \\
\text { estate market because of poor legal system? }\end{array}$ & Statistic & Std. Error \\
\hline Mean & 2.69 & 0.072 \\
\hline Median & 3.00 & \\
\hline Variance & 1.166 & \\
\hline Std. Deviation & 1.080 & \\
\hline Minimum & 1 & \\
\hline Maximum & 4 & \\
\hline Skewness & -0.276 & 0.162 \\
\hline Kurtosis & -1.191 & 0.322 \\
\hline $\begin{array}{l}\text { Q9) To what extent do you perceive a high } \\
\text { risk of loosing capital in the Indian real } \\
\text { estate market because of the chances of } \\
\text { confiscation? }\end{array}$ & Statistic & Std. Error \\
\hline Mean & 2.62 & 0.069 \\
\hline Median & 3.00 & \\
\hline Variance & 1.080 & \\
\hline Std. Deviation & 1.039 & \\
\hline Minimum & 1 & \\
\hline Maximum & 4 & \\
\hline Skewness & -0.107 & 0.162 \\
\hline Kurtosis & -1.163 & 0.322 \\
\hline $\begin{array}{l}\text { Q10) To what extent do you perceive a high } \\
\text { risk of loosing capital in the Indian real } \\
\text { estate market because of corruption? }\end{array}$ & Statistic & Std. Error \\
\hline Mean & 2.75 & 0.074 \\
\hline Median & 3.00 & \\
\hline Variance & 1.236 & \\
\hline Std. Deviation & 1.112 & \\
\hline Minimum & 1 & \\
\hline Maximum & 4 & \\
\hline Skewness & -0.280 & 0.162 \\
\hline Kurtosis & -1.297 & 0.322 \\
\hline
\end{tabular}




\begin{tabular}{|c|c|c|}
\hline $\begin{array}{c}\text { Q11) To what extent do you perceive a high } \\
\text { risk of loosing capital in the Indian real } \\
\text { estate market because of economic issues? }\end{array}$ & Statistic & Std. Error \\
\hline \hline Mean & 2.43 & 0.071 \\
\hline Median & 2.00 & \\
\hline Variance & 1.136 & \\
\hline Std. Deviation & 1.066 & \\
\hline Minimum & 1 & \\
\hline Maximum & 4 & \\
\hline Skewness & 0.153 & 0.162 \\
\hline Kurtosis & -1.206 & 0.322 \\
\hline Q12) Overall, to what extent would you \\
be worried after you invest capital in \\
the Indian real estate market? & Statistic & Std. Error \\
\hline \hline Mean & 2.59 & 0.067 \\
\hline Median & 2.00 & \\
\hline Variance & 1.017 & \\
\hline Std. Deviation & 1.008 & \\
\hline Minimum & 1 & \\
\hline Maximum & 4 & \\
\hline Skewness & 0.031 & 0.162 \\
\hline Kurtosis & -1.115 & 0.322 \\
\hline
\end{tabular}

\section{REFERENCES}

[1] Sanford J. Foreign attraction. Can Bus 2006; 79: 163-5

[2] Businessline NEWS: Adjust policies to tame inflation: Chidambaram. Chennai 2007; 1 .

[3] Newell G, Kamineni R. The significance and performance of real estate markets in India. J Real Estate Portfolio Manage 2007; 13: 161-72.

[4] Businessline. Canadian investors can look to long-term gains. Businessline 2002; 1-2.
[5] Businessline. Globalization is a source of productivity miracle Businessline 2006; 1-3.

[6] Fathei-Sedeh K, Safizadeh MH. The association between political instability and flow of foreign direct investment. Manage Int Rev 1989; 29: 4-13.

[7] Byrne K. How do consumers evaluate risk in financial products? J Financ Serv Mar 2005; 10: 21-37.

[8] Meldrum DH (2007). Country risk and foreign direct investment. Retrieved May 5, 2007, from Website of Duncan H. Meldrum: http://www.nabe.com/am99/meldrum.pdf.

[9] Markese JD, Perritt GW. Investment attitudes and portfolio decisions of individual investors. Mid-Atlantic J Bus 1985; 23: 21-31.

[10] Masters R. Study examines investors' risk-taking propensities. J Financ Plan 1989; 2: 151-5.

[11] Hamid YA. On the way to a comprehensive Palestinian housing policy. Palestine-Israel J Politics Econ Cult 1999; 6: 52-7.

[12] Schooley DK, Worden DD (2003). Generation X: understanding their risk tolerance and investment behavior. Retrieved July, 2007 from: http://www.fpanet.org/journal/articles/2003_Issues/jfp0903art8.cfm.

[13] Helik J. World watch: the 1997 global investment conference. Can Invest Rev 1997; 10: 28-39.

[14] Olsen RA. Investment risk: The experts' perspective. Financ Anal J 1997; 53: 62-67.

[15] Hooker K. 72-year-old can afford some risk. Boston Globe 1995; 76.

[16] Weiss WH. Cutting down the risks in decision making. Supery Manage 1985; 30: 14-6.

[17] Manjooran P. Two pillars of the Asian economy. Can Invest Rev 2004; 17: R19.

[18] McCleam M. India. Can Bus 2005; 78: 49-54.

[19] Cuervo-Cazurra A. Who cares about corruption. J Int Bus Stud 2006; 37: 807-22.

[20] Leggett D. India's developing automotive markets and industry 2004 management briefing: political and economic overview. JustAuto 2004; 1-1.

[21] Chakraborty SK. Business ethics in India. J Bus Ethic 1997; 16 : 1529-38.

[22] Norman W. India's reforms seen on track despite qualms over upcoming election. Res Technol Manag 1996; 39: 2-3.

[23] West GT. Political risk investment insurance: a renaissance. J Project Finance 1999; 5: 27-36.

[24] Anonymous. Investors warned of political risks in China and India EuroProperty 2007; 3-4.

[25] Galvao D. Expanding opportunities, managing risk. Can Underwriter 2005 ; 72: 54-5.

[26] Anonymous. India: risk ratings. Country Monitor 2005; 13: 11.

[27] Al-Tamimi HA. Factors influencing individual investor behavior: an empirical study of UAE financial markets. Bus Rev 2006; 5: 225-33.

(c) Gill and Biger; Licensee Bentham Open.

This is an open access article distributed under the terms of the Creative Commons Attribution License (http://creativecommons.org/license/by/2.5/), which permits unrestrictive use, distribution, and reproduction in any medium, provided the original work is properly cited. 